\title{
2-Hour Postprandial Glucose
}

National Cancer Institute

\section{Source}

National Cancer Institute. 2-Hour Postprandial Glucose. NCI Thesaurus. Code C129778.

The amount of glucose present in a sample two hours after a subject has eaten a meal. 